\title{
Pengembangan Website Media Sosial Organisasi Mahasiswa Universitas Ahmad Dahlan dengan Arsitektur Sistem Web Single Page Application
}

\author{
Setyawan Wahyu Utomo (1500018134) a,1,*, Supriyanto, S.T., M.T. (0523068801) ${ }^{\mathrm{b}, 2}$ \\ a,b Program Studi Teknik Informatika, Universitas Ahmad Dahlan \\ Jl. Kapas 9, Semaki, Umbulharjo, Yogyakarta 55166 \\ ${ }^{1}$ setyawan1500018134@webmail.uad.ac.id; ${ }^{2}$ supriyanto@tif.uad.ac.id
}

Abstrak

Universitas Ahmad Dahlan (UAD) merupakan salah satu universitas swasta yang terletak di Daerah Istimewa Yogyakarta. Perlembangan UAD tergolong sangat cepat dalam berbagai bidang, baik dari bidang akademik maupun non akademik. UAD memiliki website sistem informasi yang sangat baik, salah satunya adalah website Organisasi Mahasiswa (ORMAWA) dengan alamat https://uad.ac.id/id/ormawa/ yang dapat diakses oleh mahasiswa dosen maupun pengguna umum. Website ini memiliki fungsi sebagai pengenalan Ormawa ataupun sebagai sumber informasi tekait kegiatan Ormawa UAD. Masalah yang muncul pada website tersebut saat ini adalah mahasiswa kurang mengetahui halaman website tersebut karena Ormawa lebih sering menggunakan sosial media seperti Instagram dalam menyampaikan informasi. Namun masalah lain yang muncul adalah mahasiswa atau pengguna umum diharuskan mengikuti akun Ormawa terkait untuk mendapatkan informasi terbaru,sedangkan Ormawa UAD jumlahnya cukup banyak sehingga kurang efisien dalam penggunaan. Maka dilakukan penelitian untuk membangun kembali sosial media khusus untuk Ormawa UAD dengan tujuan memusatkan informasi pada satu halaman website sehingga mahasiswa tidak harus mengikuti seluruh akun Ormawa dan mempermudah penyampaian informasi bagi mahasiswa atau pengguna umum.

Berdasarkan permasalahan tersebut, maka dikembangkan website Media Sosial Organisasi Mahasiswa Universitas Ahmad Dahlan dengan menggunakan arsitektur sistem web Single Page Application (SPA). Adapun tahapan penelitian meliputi kebutuhan fungsional, perancangan basis data dan mockup, implementasi basis data dan pengkodean serta pengujian dengan System Usability Scale (SUS) sebagai pengujian kelayakan website berdasarkan kisaran rating penerimaan, Single Ease Question (SEQ) sebagai pengujian yang mengukur kemudahan bagi pengguna dan pengujian website dengan ekstensi Lighthouse dari Google Chrome berdasarkan dengan aspekaspek yaitu performance, accessibility dan best practices.

Hasil yang diperoleh dari perhitungan 32 data survei System Usability Scale (SUS) didapatkan niali rata-rata 70,16 dengan nilai $\mathrm{C}$ dan masuk kategori Good (Baik) berdasarjan rating penerimaan, kemudian pengujian Single Ease Question (SEQ) dengan survei 10 orang pengguna didapatkan hasil median rata-rata 5,8 dengan kategori cukup mudah, lalu pengujian website dengan ekstensi Lighthouse dari Google Chrome menghasilkan nilai Performance 50, Accessibility 80, Best Practices 86, SEO 80 dan terdapat Progressive Web Application dimana nilai tersebut lebih baik daripada website biasa tanpa arsitektur Single Page Application untuk meningkatkan user experience.

Kata Kunci: Single Page Application, Ormawa UAD, SUS, SEQ, Lighthouse 


\section{Pendahuluan}

\subsection{Latar Belakang Masalah}

Pada masa perkuliahan mahasiswa harus dapat mengembangkan potensi diri dengan mengikuti kegiatan kampus selain dari kegiatan akademik seperti organisasi mahasiswa (ORMAWA) atau kepanitiaan yang diadakan ORMAWA. Salah satu fungsi dari organisasi kemahasiswaan adalah sebagai sarana penunjang pendidikan dan sarana untuk mengembangkan kemampuan diri (soft skills) [1]. Untuk mengetahui setiap kegiatan kampus mahasiswa harus selalu update informasi baik dari papan pengumuman atau pamflet yang disebar, termasuk melihat dari media sosial seperti situs jejaring sosial Instagram ORMAWA tersebut, dimana media sosial memiliki pengaruh besar terhadap perkembangan informasi. Penulis mengambil sampel pada ORMAWA Universitas Ahmad Dahlan (UAD) yang terdiri dari tingkatan Universitas, Fakultas dan Program studi.

Kendala yang muncul adalah saat mahasiswa ingin mengetahui informasi melalui media sosial, mereka harus mengikuti setiap akun media sosial yang berbeda untuk mengetahui setiap informasi setiap ORMAWA, lalu informasi yang sering dijumpai bertumpuk dengan informasi diluar informasi ORMAWA sehingga proses penyebaran informasi tidak tersampaikan kepada mahasiswa.

Teknologi website yang akan dikembangkan untuk mengatasi masalah yang telah diuraikan, maka perlu adanya pengembangan teknologi terhadap sistem dengan menerapkan penggunaan aplikasi halaman tunggal atau atau Single Page Application (SPA). Single Page Application dapat memperbaiki kecepatan proses dibanding penggunaan halaman standar, kebutuhan transaksi request dan respon pada aplikasi yang akan dibangun yaitu server tidak lagi harus mengirimkan respon balik halaman HTML full, cukup data saja dalam format JSON (menggunakan AJAX) misalnya yang kemudian akan diolah oleh Vue [2].

Model dari SPA merupakan sistem yang merujuk pada aplikasi berbasis web yang menampilkan satu halaman saja untuk memproses sebuah tugas dengan direalisasikan dengan kode program yang dijalankan di komputer pengguna (client side scripting) [3].

\section{Metode \& Landasan Teori}

Dalam pengembangan website ini maka diperlukan pemahaman bagaimana sistem dapat berjalan dan mengethaui sistem dapat bekerja dengan baik maka landasan teori dalam penelitian ini terlihat pada Gambar 1.
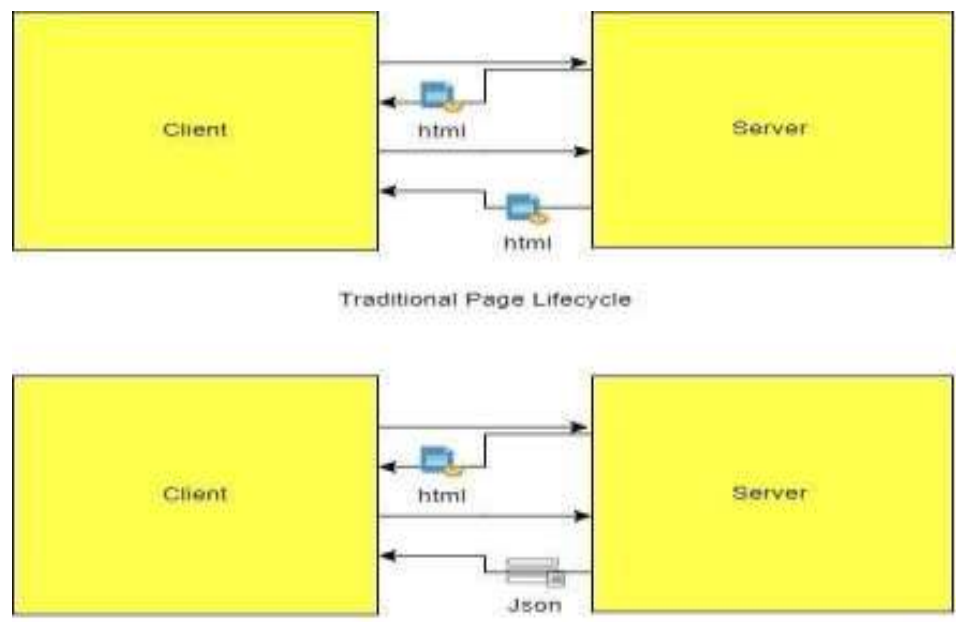

SPA Lifecycle

Gambar 1 Single Page Application lifecycle

1. Metode Model-View-Controller (MVC) untuk pengembangan aplikasi berbasis WEB yang mana aplikasi dapat dibagi-bagi dalam tiga bagian utama yaitu Model, sebagai bagian kode aplikasi yang berhubungan dengan basis data, kemudian View, sebagai bagian kode yang 
berhubungan dengan tampilan ke pengguna dan Controller, sebagai bagian kode yang menghubungkan antara Model dan View [4].

2. Single Page Application (SPA) merujuk pada aplikasi berbasis web yang hanya menampilkan satu halaman saja. Artinya, meskipun pengguna beralih ke menu lain, URL tidak menunjukkan perubahan. Semua komponen utama pada SPA, seperti CSS, skrip dan sumber daya lain yang diperlukan diambil pada satu waktu di halaman utama. Komponen atau konten yang sesuai diambil secara dinamis tergantung pada kebutuhan interaksi atau permintaan pengguna [3].

\section{Hasil dan Pembahasan}

\subsection{Implementasi sistem}

a. Use case diagram

Untuk mendapatkan gambaran mengenai sistem yang akan dibangun maka di modelkan dengan diagram use case sebagai berikut :

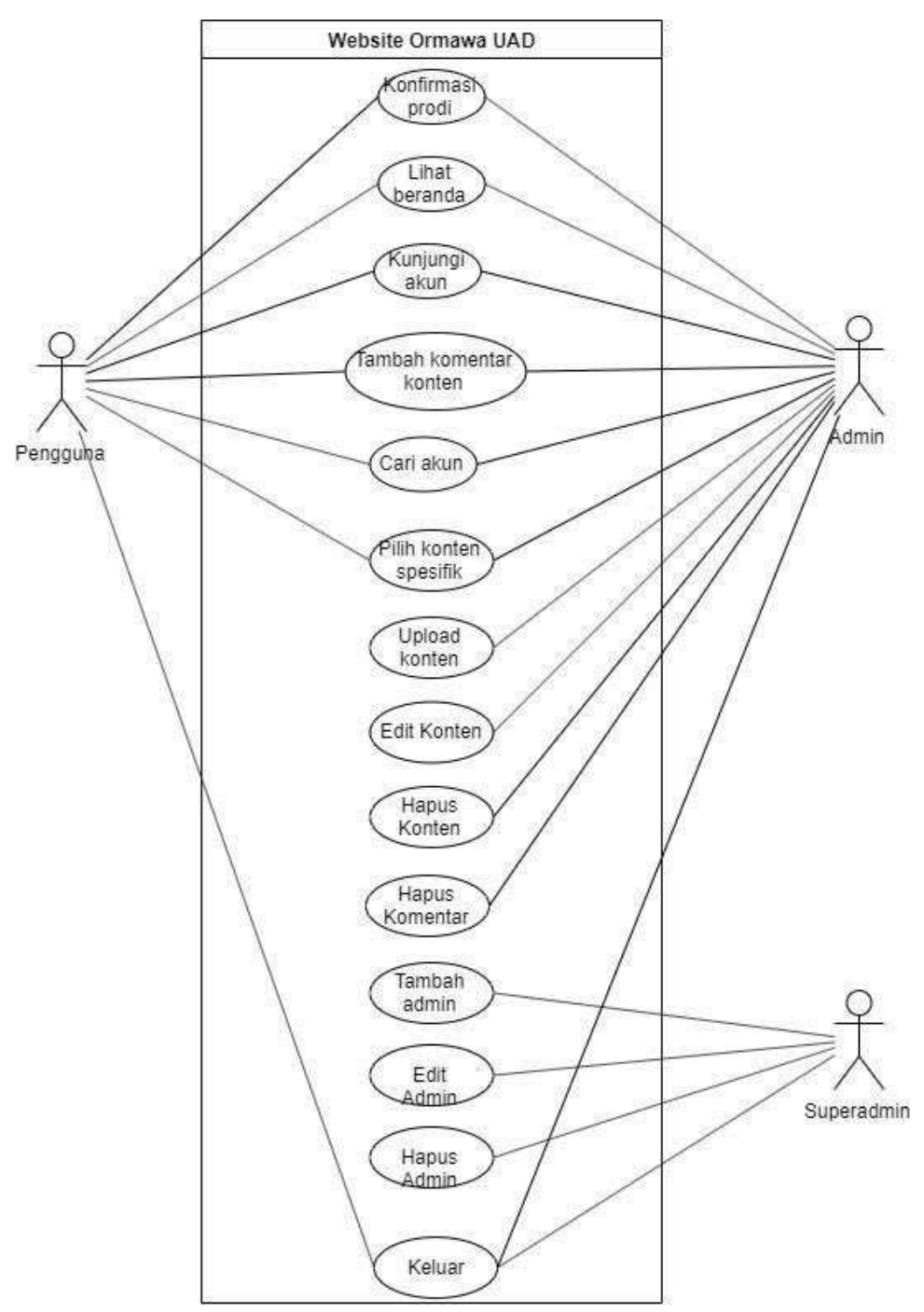

Gambar 2 Implementasi basis data

Pada Gambar 2 terdiri dari tabel Admin, Posting, Komentar dan Kunjungan. Pada tabel Admin terdapat primary key idadmin yang dimana terhubung pada pengirim, dimana pengirim akan 
digunakan pada tabel posting untuk upload dan filter konten oleh pengguna yang akan muncul pada halaman Beranda.

Pada tabel Posting terdapat primary key idposting yang dimana terhubung dengan tabel komentar yang berfungsi untuk memisahkan komentar postingan dengan komentar postingan yang lain.

Kemudian terdapat tabel komentar, pada tabel ini tidak terhubung dengan tabel yang lain karena hanya digunakan untuk menampilkan jumlah kunjungan pada setiap halaman akun ormawa yang di akses.

\subsection{Implementasi}

a. Implementasi antarmuka pengguna atau front-end adalah bentuk desain sistem kedalam bahasa pemrograman. Dalam penelitian ini digunakan Vue.js dalam mengimplementasi desain.

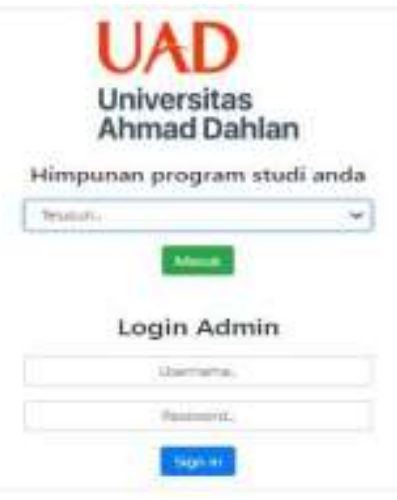

Gambar 3 Halaman Konfirmasi

Pada bagian ini merupakan halaman konfirmasi dimana pengguna mencari dan memfilter konten yang akan muncul pada beranda pengguna. Kemudian terdapat fitur Login Admin dimana form harus diinput untuk dapat masuk ke dalam halaman Admin. Hal ini terlihat pada Gambar 3.

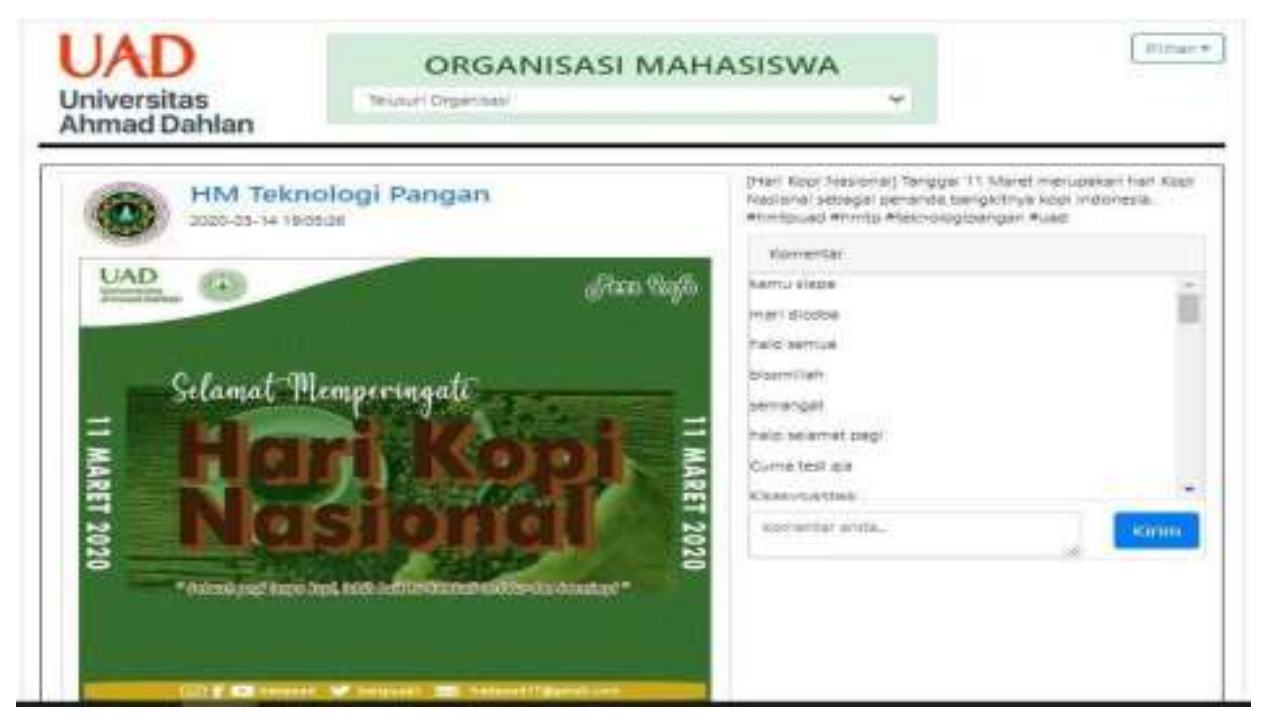

Gambar 4 Halaman beranda

Terdapat fitur pencarian ormawa, login admin, dan logout untuk keluar dari halaman beranda pada bagian header website kemudian fitur utama dari beranda adalah menampilkan postingan serta komentar untuk pengguna yang berfungsi untuk kritik, saran atau bertanya tentang postingan terkait. Hal tersebut terlihat pada Gambar 4. 


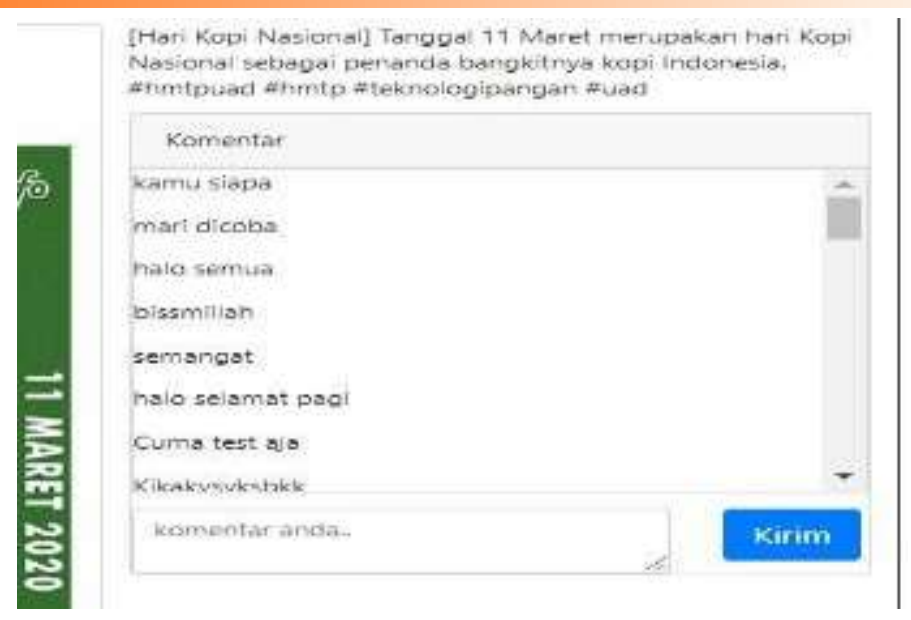

Gambar 5 Fitur komentar

Pada kolom komentar menampilkan komentar dari pengguna, baik komentar dalam bentuk pertanyaan maupun kritik dan saran. Hal tersebut ditunjukkan pada Gambar 5.

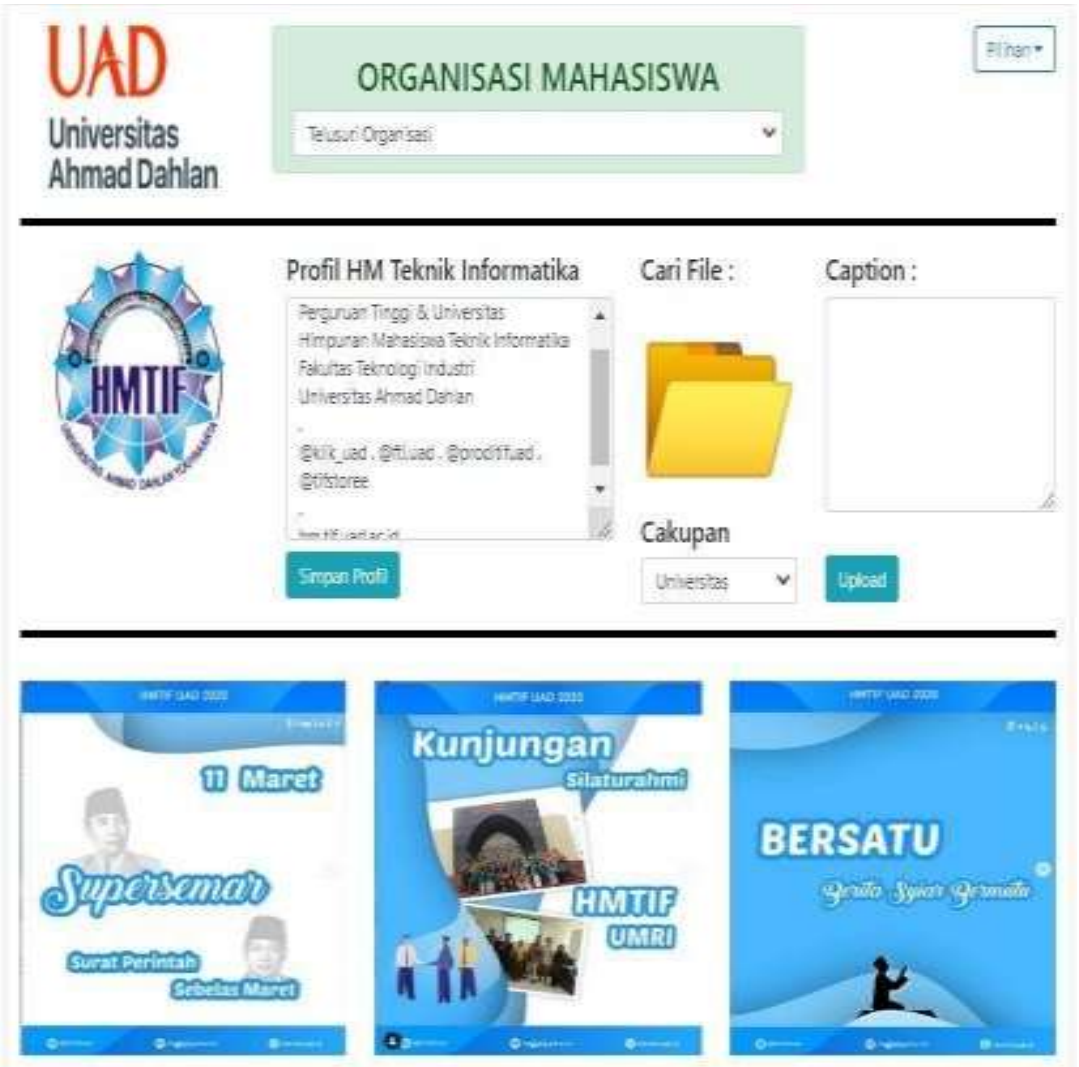

Gambar 6 halaman Admin

Bagian ini merupakan halaman admin ormawa dimana admin memposting konten, edit konten dan hapus konten termasuk edit komentar setiap postingan seperti terlihat pada Gambar 6.

\section{Pengujian}

\subsection{Pengujian Single Ease Question (SEQ)}

Dari pengujian yang dilakukan didapatkan hasil dari pengujian posttask dengan metode SEQ dengan tugas F1 sampa F5 didapatkan data dengan hasil pada Tabel 1. 
Tabel 1 Tabel Responden SEQ

\begin{tabular}{|c|c|c|c|c|c|c|}
\hline \multirow{2}{*}{ No } & \multirow{2}{*}{ Nama } & \multicolumn{5}{|c|}{ Tugas (Skala Likert) } \\
\cline { 2 - 7 } & Login & Beranda & Spesifik & Admin & Logout \\
\hline 1 & Responden 1 & 7 & 6 & 4 & 5 & 7 \\
\hline 2 & Responden 2 & 6 & 5 & 6 & 4 & 6 \\
\hline 3 & Responden 3 & 7 & 5 & 5 & 4 & 6 \\
\hline 4 & Responden 4 & 6 & 5 & 4 & 6 & 6 \\
\hline 5 & Responden 5 & 6 & 7 & 6 & 6 & 7 \\
\hline 7 & Responden 6 & 6 & 7 & 4 & 5 & 6 \\
\hline 8 & Responden 7 & 5 & 5 & 4 & 3 & 6 \\
\hline 9 & Responden 8 & 6 & 4 & 5 & 5 & 6 \\
\hline 10 & Responden 9 & 6 & 7 & 6 & 6 & 7 \\
\hline & Rata-rata Skala & 6,2 & 5,8 & 5 & 5 & 6,4 \\
\hline Median rata-rata Skala & & 7 & 6 & 6 & 7 \\
\hline
\end{tabular}

Dari tabel diatas didapatkan hasil 5.8, pada skala likert nilai tersenut masuk dalam kategori cukup mudah.

\subsection{Pengujian System Usability Scale (SUS)}

Selanjutnya pada pengujian poststudy menggunakan metode SUS diperoleh hasil dari kuesioner seperti pada Tabel 2.

Tabel 2 Tabel responden dan perhitungan SUS

\begin{tabular}{|r|r|r|r|r|r|r|r|r|r|r|r|r|r|}
\hline Responden & T1 & T2 & T3 & T4 & T5 & T6 & T7 & T8 & T9 & T10 & Subtotal & $\begin{array}{r}\text { SubTotal } \\
\text { x 2,5 }\end{array}$ & Ratarata \\
\hline 1 & 3 & 2 & 2 & 2 & 2 & 3 & 3 & 2 & 2 & 2 & 23 & 57,5 & \\
\hline 2 & 3 & 2 & 4 & 3 & 3 & 3 & 3 & 4 & 3 & 4 & 32 & 80 & \\
\hline 3 & 2 & 3 & 3 & 4 & 2 & 3 & 4 & 4 & 2 & 4 & 31 & 77,5 & \multirow{2}{*}{70,16} \\
\hline 4 & 4 & 3 & 3 & 4 & 2 & 4 & 3 & 4 & 4 & 4 & 35 & 87,5 & \\
\hline 5 & 4 & 3 & 3 & 1 & 4 & 2 & 3 & 3 & 3 & 3 & 29 & 72,5 & \\
\hline 6 & 2 & 1 & 2 & 2 & 3 & 2 & 4 & 1 & 4 & 2 & 23 & 57,5 & \\
\hline
\end{tabular}




\begin{tabular}{|c|c|c|c|c|c|c|c|c|c|c|c|c|}
\hline 7 & 2 & 2 & 1 & 2 & 3 & 3 & 4 & 2 & 3 & 3 & 25 & 62,5 \\
\hline 8 & 2 & 3 & 3 & 2 & 3 & 3 & 3 & 3 & 3 & 2 & 27 & 67,5 \\
\hline 9 & 3 & 2 & 3 & 2 & 3 & 3 & 2 & 2 & 2 & 3 & 25 & 62,5 \\
\hline 10 & 3 & 1 & 1 & 3 & 2 & 3 & 3 & 2 & 1 & 1 & 20 & 50 \\
\hline 11 & 2 & 2 & 2 & 3 & 2 & 1 & 1 & 2 & 2 & 2 & 19 & 47,5 \\
\hline 12 & 1 & 1 & 3 & 1 & 3 & 1 & 3 & 1 & 3 & 1 & 18 & 45 \\
\hline 13 & 3 & 2 & 2 & 2 & 2 & 1 & 3 & 1 & 3 & 1 & 20 & 50 \\
\hline 14 & 3 & 2 & 2 & 3 & 2 & 3 & 1 & 3 & 2 & 3 & 24 & 60 \\
\hline 15 & 2 & 3 & 2 & 2 & 2 & 2 & 2 & 2 & 2 & 2 & 21 & 52,5 \\
\hline 16 & 3 & 1 & 3 & 1 & 3 & 1 & 3 & 1 & 3 & 1 & 20 & 50 \\
\hline 17 & 4 & 3 & 4 & 3 & 3 & 4 & 4 & 4 & 3 & 4 & 36 & 90 \\
\hline 18 & 4 & 3 & 4 & 4 & 3 & 1 & 4 & 4 & 2 & 4 & 33 & 82,5 \\
\hline 19 & 3 & 2 & 3 & 3 & 3 & 3 & 3 & 3 & 4 & 3 & 30 & 75 \\
\hline 20 & 4 & 2 & 3 & 3 & 4 & 3 & 4 & 3 & 3 & 3 & 32 & 80 \\
\hline 21 & 4 & 2 & 3 & 1 & 2 & 3 & 3 & 2 & 2 & 1 & 23 & 57,5 \\
\hline 22 & 3 & 3 & 2 & 2 & 3 & 2 & 3 & 3 & 2 & 2 & 25 & 62,5 \\
\hline 23 & 3 & 2 & 2 & 2 & 3 & 3 & 3 & 3 & 4 & 2 & 27 & 67,5 \\
\hline 24 & 4 & 2 & 2 & 2 & 3 & 2 & 2 & 3 & 2 & 3 & 25 & 62,5 \\
\hline 25 & 4 & 4 & 4 & 4 & 2 & 3 & 4 & 4 & 3 & 4 & 36 & 90 \\
\hline 26 & 4 & 2 & 4 & 2 & 4 & 3 & 3 & 4 & 3 & 3 & 32 & 80 \\
\hline 27 & 4 & 0 & 4 & 1 & 4 & 1 & 4 & 2 & 2 & 3 & 25 & 62,5 \\
\hline 28 & 4 & 3 & 3 & 3 & 4 & 3 & 4 & 4 & 3 & 4 & 35 & 87,5 \\
\hline 29 & 3 & 2 & 4 & 4 & 4 & 4 & 4 & 4 & 3 & 4 & 36 & 90 \\
\hline 30 & 4 & 3 & 4 & 4 & 3 & 3 & 4 & 4 & 4 & 4 & 37 & 92,5 \\
\hline 31 & 4 & 4 & 4 & 4 & 4 & 4 & 4 & 4 & 4 & 4 & 40 & 100 \\
\hline
\end{tabular}




\begin{tabular}{|l|l|l|l|l|l|l|l|l|l|l|l|l|}
\hline 32 & 2 & 3 & 4 & 4 & 2 & 4 & 4 & 4 & 3 & 4 & 34 & 85 \\
\hline
\end{tabular}

Pada pengujian post-task menggunakan metode SEQ nilai median 5,8 dimana dilihat pada Tabel 2 skala SEQ mendapatkan hasil tidak sulit menurut para responden.

Tabel 3 Kisaran rating penerimaan

\begin{tabular}{|c|c|}
\hline Skor & Hasil \\
\hline 1 & Sangat sulit \\
\hline 2 & Sulit \\
\hline 3 & Tidak mudah \\
\hline 4 & Cukup \\
\hline 5 & Tidak sulit \\
\hline 6 & Mudah \\
\hline 7 & Sangat mudah \\
\hline
\end{tabular}

Selanjutnya pada pengolahan data dari pengujian poststudy dengan metode SUS pada Tabel 3 diperoleh rata-rata skor SUS sebesar 70,16. Untuk skala penilaian metode SUS dapat dilihat pada Gambar 12 yang berarti skor SUS sebesar 70,16 mendapatkan nilai $C$ dan masuk kategori baik jika dikonversikan menurut kisaran rating penerimaan.

\subsection{Pengujian Response Time}

Pada pengujian Response Time penelitian ini membandingkan antara website menggunakan SPA dengan website halaman yang sama tetapi tanpa menggunakan SPA atau menggunakan bahasa PHP murni. Hasil perbandingan menggunakan ekstensi Lighthouse terlihat pada Gambar 7 dan Gambar 8 .

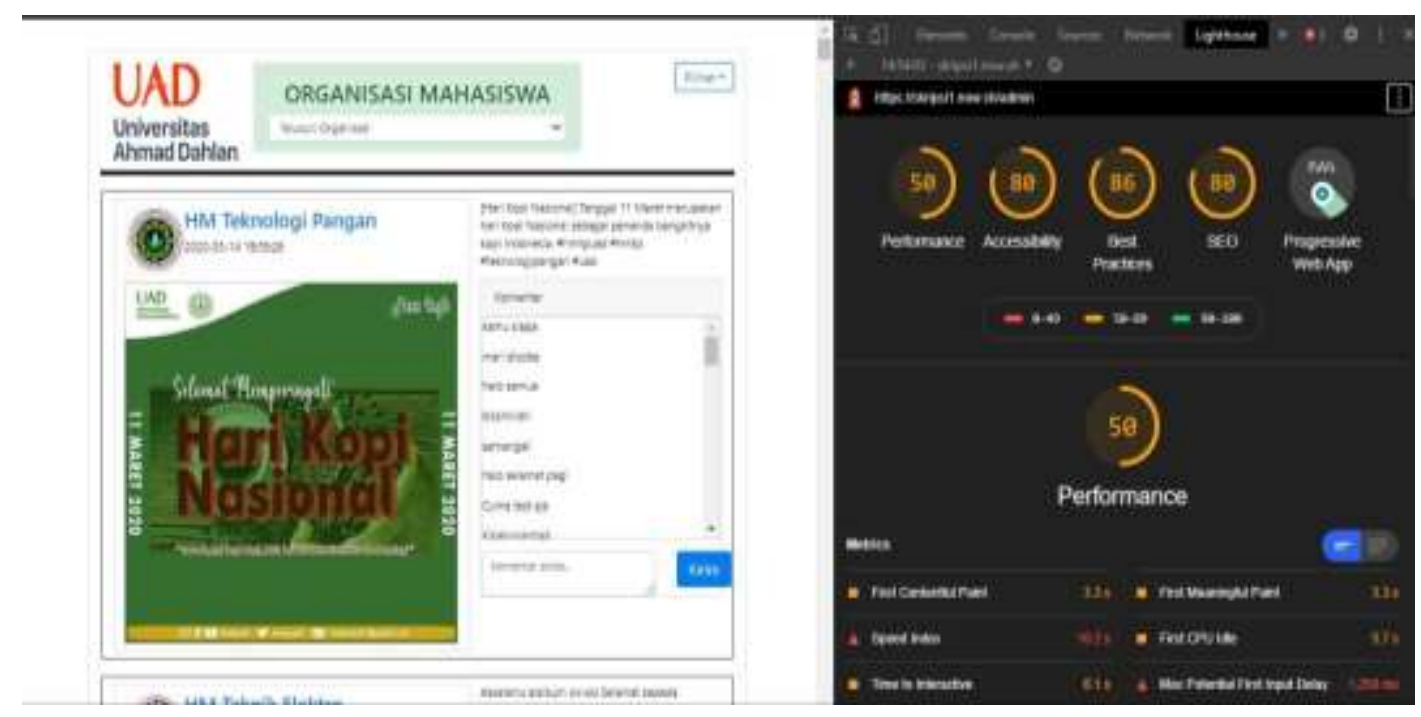

Gambar 7 Hasil pengujian website menggunakan SPA 


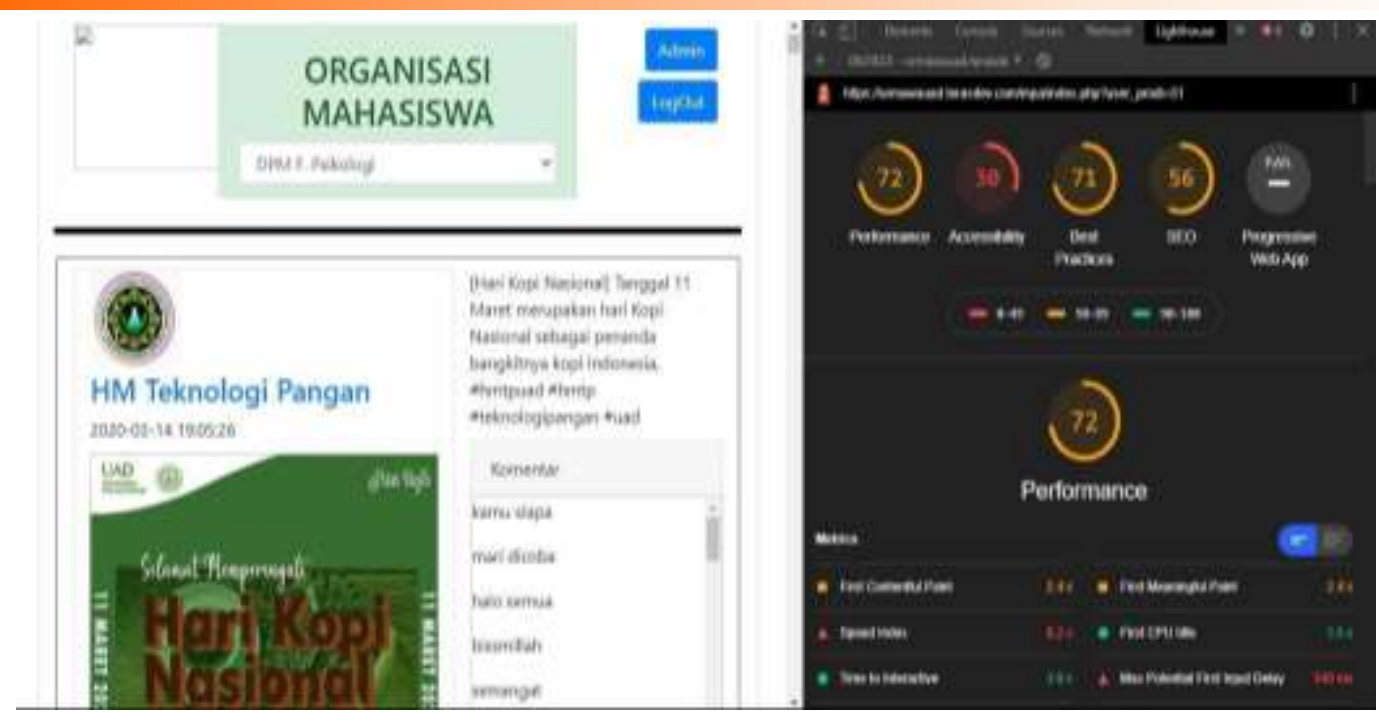

Gambar 8 Hasil pengujian website tanpa SPA

Kemudian dari hasil tersebut didapatkan nilai yang dikonversi kedalam Tabel 4 dan Tabel 5.

Tabel 4 Pengujian website dengan SPA

\begin{tabular}{|c|c|c|}
\hline \multicolumn{3}{|c|}{ Hasil pengujian Lighthouse Website menggunakan Single Page Application } \\
\hline Performance & 50 & \\
\hline Accessibility & 80 & Ratarata \\
\hline Best practices & 86 & \\
\hline SEO & 80 \\
\hline PWA & Ya \\
\hline
\end{tabular}

Tabel 5 Pengujian website tanpa SPA

\begin{tabular}{|c|c|c|}
\hline \multicolumn{2}{|c|}{$\begin{array}{c}\text { Hasil pengujian Lighthouse Website tanpa } \\
\text { menggunakan Single Page Application }\end{array}$} \\
\hline Performance & 72 & Ratarata \\
Accessibility & 30 & \\
\cline { 1 - 2 } Best practices & 71 & \\
\cline { 1 - 2 } SEO & 56 & \\
\hline PWA & Tidak & \\
\hline
\end{tabular}


Maka dari hasil Lighthouse pengujian website bahwa hasil rata-rata dari pengujian Lighthouse dengan Single Page Application adalah 74 sedangkan pengujian tanpa Single Page Application adalah 57,52 maka dapat disimpulkan bahwa website dengan Single Page Application lebih baik dari website tanpa menggunakan Single Page Application

\section{Kesimpulan dan saran}

\subsection{Kesimpulan}

Berdasarkan hasil penelitian yang dihasilkan, dapat disimpulkan bahwa Pengembangan Website Media Sosial Organisasi Mahasiswa Universitas Ahmad Dahlan Dengan Arsitektur Sistem Web Single Page Application sudah mendapatkan nilai SEQ yaitu hasil dari median seluruh tugas F1 sampai F5 adalah 5,8 dengan kategori cukup mudah digunakan pengguna. Kemudian skor SUS sebesar 70,16 mendapatkan nilai $\mathrm{C}$ dan masuk kategori baik jika dikonversikan menurut kisaran rating penerimaan dari kuisioner pengguna. Serta hasil rata-rata dari pengujian Lighthouse website SPA adalah 74 sedangkan pengujian tanpa Single Page Application adalah 57,52 maka dapat disimpulkan bahwa website dengan SPA dapat memberikan UX yang baik terhadap pengguna.

\subsection{Saran}

Adapun saran untuk penelitian selanjutnya adalah sebagai berikut :

1. Melakukan pengujian loading data dengan Vue LazyLoad dimana data lama pada beranda tidak ikut dimuat pada saat akses.

2. Desain interface masih cukup kaku sehingga perlu adanya pengembangan pada desain interface menggunakan metode Progresive Web App untuk dapat diakses pada banyak perangkat.

\section{Daftar Pustaka}

[1] K. Kosasih, "Peranan Organisasi Kemahasiswaan Dalam Pengembangan Civic Skills Mahasiswa," J. Pendidik. Ilmu Sos., vol. 25, no. 2, pp. 188-198, 2017.

[2] P. Späth, "Building Single-Page Web Applications with REST and JSON," in Beginning Jakarta EE, Springer, 2019, pp. 133-163.

[3] A. Ristyabudi and H. Thamrin, "Penerapan Single Page Application pada Proses Pengisian Online Data Rencana Studi Mahasiswa," Khazanah Inform. J. Ilmu Komput. dan Inform., vol. 2, no. 1, pp. 1-9, 2016.

[4] D. Wismarini and H. Murti, "PENGGUNAAN MODEL VIEW CONTROLLER (MVC) DALAM PERANCANGAN MODEL APLIKASI WEBGIS UNTUK INFORMASI RENTAN BANJIR DI SEMARANG,” 2018. 